\title{
The Detection of Flood Characteristics Alteration Induced by the Danjiangkou Reservoir at Han River, China
}

\author{
Xiao Zhang *, Baofei Feng, Jun Zhang, Yinshan Xu, Jie Li, Wenjing Niu and Yanfei Yang \\ Bureau of Hydrology, Changiiang Water Resources Commission, Wuhan 430010, China; fengbf@cjh.com.cn (B.F.); \\ zhangjun@cjh.com.cn (J.Z.); xuys@cjh.com.cn (Y.X.); lij@cjh.com.cn (J.L.); niuwj@cjh.com.cn (W.N.); \\ yangyf@cjh.com.cn (Y.Y.) \\ * Correspondence: zxhhu1991@163.com; Tel.: +86-152-4023-3358
}

Citation: Zhang, X.; Feng, B.; Zhang, J.; Xu, Y.; Li, J.; Niu, W.; Yang, Y. The Detection of Flood Characteristics Alteration Induced by the Danjiangkou Reservoir at Han River, China. Water 2021, 13, 496. https://doi.org/ 10.3390/w13040496

Academic Editor: Fi-John Chang

Received: 9 January 2021

Accepted: 5 February 2021

Published: 14 February 2021

Publisher's Note: MDPI stays neutral with regard to jurisdictional claims in published maps and institutional affiliations.

Copyright: (c) 2021 by the authors. Licensee MDPI, Basel, Switzerland. This article is an open access article distributed under the terms and conditions of the Creative Commons Attribution (CC BY) license (https:// creativecommons.org/licenses/by/ $4.0 /)$.

\begin{abstract}
As one of the most common natural phenomena, floods can bring both risks and benefits for human beings. They can pose a risk of inundation to a human habitat but can also be utilized as a resource with hydraulic engineering. Improving the knowledge of flood characteristics is the basis and premise of improving water resources management and ecological environmental protection. Presently, the quantitative evaluation of flood characteristics needs to gradually evolve from a single indicator to a systematic one. In this paper, by introducing the concepts of ecohydrology on magnitude, frequency, and duration, a set of flood characteristics indicators evaluation system is constructed based on the hydrological characteristics for the section where Danjiangkou Reservoir is located at the middle reach of the Yangtze in China. The results showed that the Danjiangkou Reservoir has changed the flood characteristics to a great extent both of seasonal or annual floods, and the mean degree of the flood characteristic alteration indicators is about $19 \%$. The changing trend of the flood indicators upstream showed an increasing trend from the 1970s to 2010s, while downstream were divided into two periods by the year of about 1975. The methodological system provided by this paper can effectively evaluate flood characteristics quantitatively, provide technical guidance and a useful reference for flood process analysis, and provide support for flood management and river ecosystem protection.
\end{abstract}

Keywords: flood characteristics; quantitative evaluation; alteration; Danjiangkou Reservoir

\section{Introduction}

As the most important object in the study of natural phenomena, floods have always been the focus of attention of scientists and engineers on their evolutions and characteristics. With the dual impact of climate change and human activities [1,2], the flood regimes of many large rivers around the world have changed significantly [3-5]; this has had a profound impact on regional flood control safety, water resources utilization, ecological protection, etc. Therefore, it is of great scientific importance how to describe floods objectively. Usually, there are two ways for describing a flood: one is simulated flood processes through hydrological and hydrodynamic models [6-8], and another is to establish indicators through hydrological statistics methodology for characterizing floods [9-11]. In terms of model simulations, the models have made obvious progress in regional-scale compatibility [12], stability [13], and uncertainty reductions [14], which has led to a significant improvement in the accuracy and applicability of flood simulations. In terms of hydrological indicator statistics, extreme value theory provides a firm theoretical foundation for the statistical modeling of extreme hydrological events; currently, the most commonly used indicators are block maxima (BM) and peak-over-threshold (POF) [15]. Moreover, some studies have combined meteorological and hydrological elements to establish some simplified indicators for characterizing flood processes, such as monthly rainfall [16], rainy season rainfall [17], maximum daily annual floods, and precipitation [18,19]. These indicators are well-adapted to the disciplines of water resources engineering, flood frequency analysis, 
and project impact evaluation. However, such quantitative indicators and methods for evaluation and analysis for the variation of flood characteristics [20,21] still has limitations, mainly in which the indicators are too singular and do not constitute a system, can just reflect an aspect of flood characteristic and it is difficult to fully reflect the characteristics of floods.

In contrast, in the field of ecological hydrology, the method of IHA which derived from the ecohydrological paradigm used a large number of indicators for describing the hydrological process in response to ecology [22,23]. This indicator system has been used for hydrological regime impact assessment and ecohydrological effect research. Among them, the concepts such as flood magnitude, frequency, and duration can be introduced and redefined as indicators for flood characteristics evaluation. By referring to these concepts, we can more comprehensively, objectively, and accurately describe the flood process and characteristics, which has a great significance for studying the flood changing regularity, water resource management, and harmony between environment and society.

As the largest trans-century projects in China, The South-to-North Water Diversion Project (S2N) is aimed at transferring water from Southern China to Northern China to meet the increasing demand for water resources in Northern China, where the storage of water has been a serious constraint to the regional economic development and ecological security [24,25]. As the source of the middle route of S2N, Danjiangkou Reservoir, which is the largest water control project of the Han River basin, controls the upper Han River and Dan River, with a total catchment area of approx. $95,200 \mathrm{~km}^{2}$, and it has a total storage capacity of 33.91 billion $\mathrm{m}^{3}$. For the reservoir, on the premise of ensuring flood control safety, continuous water supply to the northern region of China has a great significance to ensure the coordinated development of China's regional economy.

Therefore, this paper conducts a systematic study from three levels (Figure 1): indicators system, evaluation method, and flood characteristics analysis. The flooding process upstream and downstream of the reservoir of the Danjiangkou in Han River for the period of 1967-2015 is selected as the study object, a set of quantitative indicators system which include magnitude, duration, and frequency of flood characteristics is established, and a series of statistical analysis methods are adopted to study the differences and trends of flood characteristics systematically.

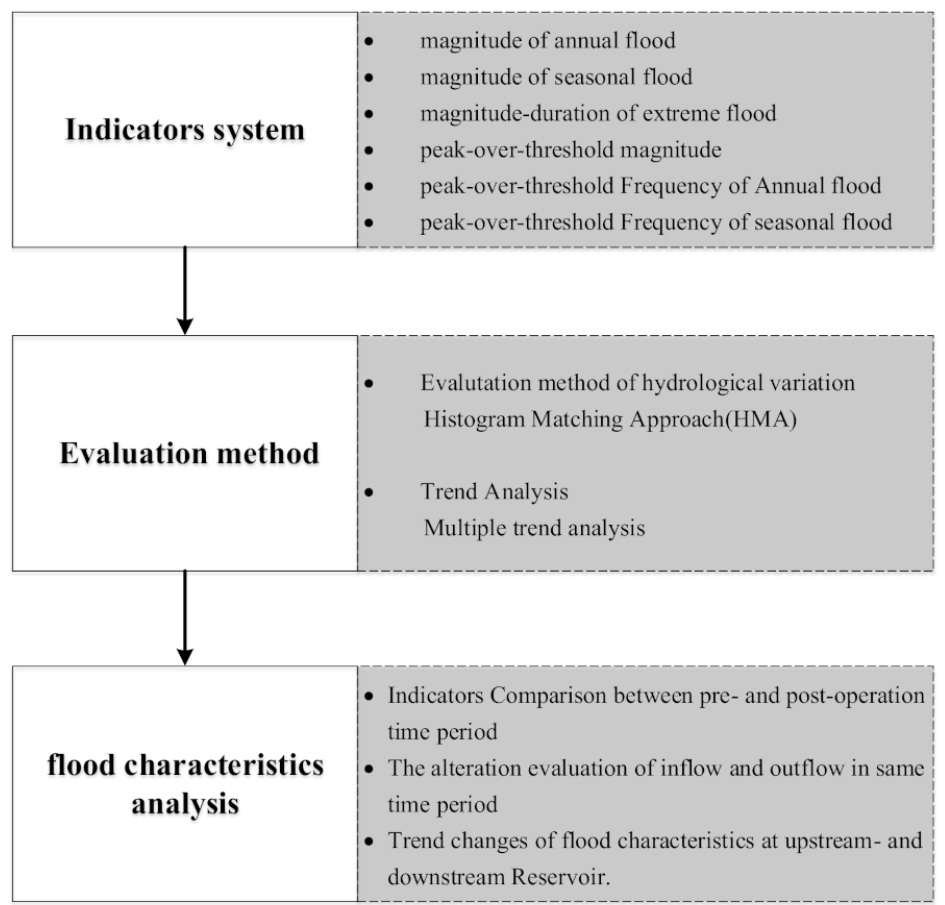

Figure 1. Schematic analysis methodology. 


\section{Materials and Methods}

\subsection{Study Area}

The Han River basin has a drainage area of $159,000 \mathrm{~km}^{2}$ and is the largest tributary at the middle reaches of the Yangtze river, which is about $1567 \mathrm{~km}$ long. It rises in the south of Qinling Mountains, flows southeast through the Qinba Mountains, and imports into Danjiangkou Reservoir; after outflowing the reservoir, it flows across the Jianghan Plain and joins into Yangtze River from Wuhan, the economic and cultural center city of Middle China. The mainstream of the Han River traverses through Shanxi and Hubei Provinces, and its tributaries extend in the Gansu, Sichuan, Henan, and Chongqing four provinces and cities. The basin belongs to the north subtropic monsoon climatic region with remarkable transitional climatic characteristics (spatial and temporal patterns of the water quality in the Danjiangkou Reservoir, China), which are affected by the Eurasian-Continental cold high pressure in the winter and the Western Pacific subtropical high in the summer. The basin annual mean temperature is $12-17^{\circ} \mathrm{C}$, of which the highest in July and the lowest in January. The annual mean precipitation amounts to $700-1100 \mathrm{~mm}$, which increases from upper reaches to down reaches.

Danjiangkou Reservoir, the largest water control project of the Han River basin, controls the upper Han River and Dan River, with a total catchment area of approx. $95,200 \mathrm{~km}^{2}$ (the Han River watershed management initiative for the South-to-North Water Diversion Project (Middle Route) of China). The dam has a length of $2949 \mathrm{~m}$ and a crest elevation of $176.6 \mathrm{~m}$. The Danjiangkou project began construction on September 1958 and started impounding water on 18 November 1967, and the first-phase project ended in February 1974; in that time, the reservoir had a total storage capacity of 23.16 billion $\mathrm{m}^{3}$. For improving the reservoir's comprehensive benefits of flood control, water supply, power generation, and shipping, the second-phase project began in 2005 and heightened and strengthened the dam and expanded the total storage capacity to 33.91 billion $\mathrm{m}^{3}$, and the reservoir transformed the operation from annual regulating to multi-annual regulating.

For detecting the flood characteristics and the alterations that may be caused by the reservoir, the daily streamflow data of an important outflow hydrological control station (Figure 2) downstream of the Danjiangkou reservoir, named Huangjiagang, was obtained from the Hydrological Bureau of the Yangtze River Water Resources Commission, China. The timing of the Danjiangkou reservoir impoundment (in 1967) was used as a changing point to divide the preoperation (1957-1966) and post-operation (1967-2015) periods. Besides, we also obtained the daily inflow data (1967-2015) of the Danjiangkou Reservoir, which was calculated by both the water stage capacity relationship and discharge.

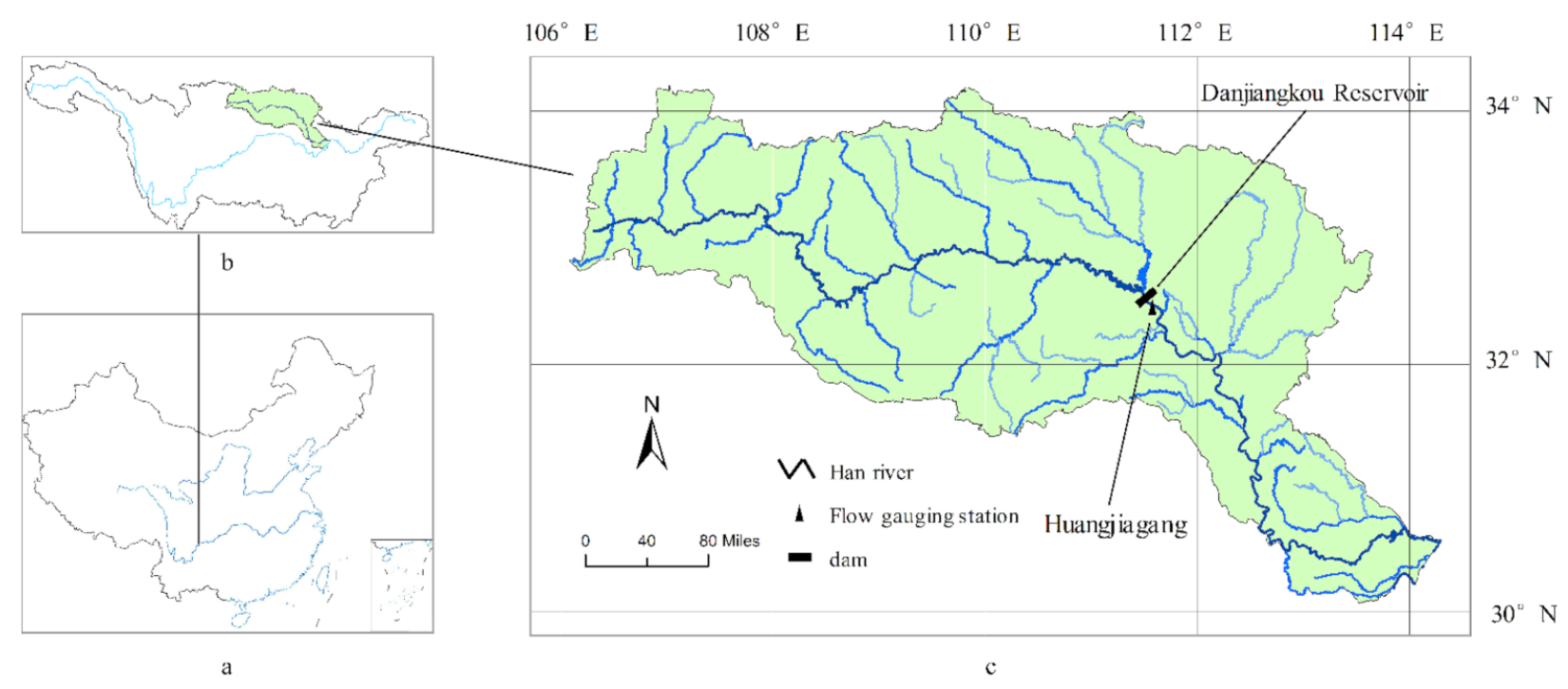

Figure 2. Sketch map of Han River and the location of the Danjiangkou Reservoir. (Map a is the border of China. Map b is the border of the Yangtze River Basin. Map c is the border of the Han River Basin.). 


\subsection{Flood Characteristic Indicators}

To quantify the flood characteristics, the indicators which can describe the magnitude, frequency, and duration were selected (Table 1). These comprise the annual maximum streamflow series; seasonal maximum streamflow series; peak-over-threshold series (POT); and magnitude-duration of annual extreme flood conditions series (such as annual maxima 3-day, 5-day, 7-day, 15-day, 30-day, 90-day flood volumes or mean flow). Annual maximum daily mean streamflow, i.e., the largest daily mean streamflow that occurs in each hydrological year, is the most common indicator for quantitatively describing the flood magnitude characteristics. In some studies [26,27], peak-over-threshold series were used, since they are considered to include more flood characteristic information, thus allowing to reveal better the temporal pattern of flood occurrence. Besides, lots of research on hydrological regime evaluations have mentioned that the magnitude duration of annual extreme flood conditions series can better reflect the characteristics of the relationship between duration and magnitude of flood process [28-30].

Table 1. Flood characteristics indicators system.

\begin{tabular}{|c|c|c|c|}
\hline Statistics Group & Flood Indicators & Abbreviation & Remarks \\
\hline \multirow{3}{*}{$\begin{array}{l}\text { magnitude of annual } \\
\text { and seasonal flood }\end{array}$} & $\begin{array}{l}\text { Annual maximum daily mean } \\
\text { streamflow }\left(\mathrm{m}^{3} / \mathrm{s}\right)\end{array}$ & AMDXS & $\begin{array}{l}\text { Maximum discharge for each hydrological year } \\
\text { (1 March-28 (29) February) }\end{array}$ \\
\hline & $\begin{array}{l}\text { Annual spring-summer } \\
\text { maximum daily mean } \\
\text { streamflow }\left(\mathrm{m}^{3} / \mathrm{s}\right)\end{array}$ & ASSMDXS & $\begin{array}{l}\text { Maximum discharge for each spring and } \\
\text { summer (1 March-31 August) }\end{array}$ \\
\hline & $\begin{array}{l}\text { Annual autumn-winter maximum } \\
\text { daily mean streamflow }\left(\mathrm{m}^{3} / \mathrm{s}\right)\end{array}$ & AAWMDXS & $\begin{array}{l}\text { Maximum discharge for each autumn and winter } \\
\text { (1 September-28(29) February) }\end{array}$ \\
\hline \multirow{5}{*}{$\begin{array}{l}\text { magnitude-duration } \\
\text { of annual extreme } \\
\text { flood conditions }\end{array}$} & $\begin{array}{l}\text { Annual maximum 3-day mean } \\
\text { streamflow }\left(\mathrm{m}^{3} / \mathrm{s}\right)\end{array}$ & AM3DXS & $\begin{array}{c}\text { Maximum mean discharge of } 3 \text { days each } \\
\text { hydrological year }\end{array}$ \\
\hline & $\begin{array}{l}\text { Annual maximum 7-day mean } \\
\text { streamflow }\left(\mathrm{m}^{3} / \mathrm{s}\right)\end{array}$ & AM7DXS & $\begin{array}{c}\text { Maximum mean discharge of } 7 \text { days each } \\
\text { hydrological year }\end{array}$ \\
\hline & $\begin{array}{l}\text { Annual maximum } 15 \text {-day mean } \\
\text { streamflow }\left(\mathrm{m}^{3} / \mathrm{s}\right)\end{array}$ & AM15DXS & $\begin{array}{l}\text { Maximum mean discharge of } 15 \text { days each } \\
\text { hydrological year }\end{array}$ \\
\hline & $\begin{array}{l}\text { Annual maximum 30-day mean } \\
\text { streamflow }\left(\mathrm{m}^{3} / \mathrm{s}\right)\end{array}$ & AM30DXS & $\begin{array}{c}\text { Maximum mean discharge of } 30 \text { days each } \\
\text { hydrological year }\end{array}$ \\
\hline & $\begin{array}{l}\text { Annual maximum 90-day mean } \\
\text { streamflow }\left(\mathrm{m}^{3} / \mathrm{s}\right)\end{array}$ & AM90DXS & $\begin{array}{c}\text { Maximum mean discharge of } 90 \text { days each } \\
\text { hydrological year }\end{array}$ \\
\hline \multirow{4}{*}{$\begin{array}{l}\text { peak-over-threshold } \\
\text { series }\end{array}$} & $\begin{array}{l}\text { Peak-over-threshold } \\
\text { magnitude }\left(\mathrm{m}^{3} / \mathrm{s}\right)\end{array}$ & РОТЗХM & $\begin{array}{l}\text { Discharge peaks above threshold; on average } \\
\text { three events per year }\end{array}$ \\
\hline & Peak-over-threshold frequency & POT3XF & $\begin{array}{l}\text { Annual number of discharge peaks above } \\
\text { threshold; on average three events per year }\end{array}$ \\
\hline & $\begin{array}{c}\text { Spring-summer } \\
\text { peak-over-threshold frequency }\end{array}$ & SSPOT3XF & $\begin{array}{c}\text { Annual number of spring and summer discharge } \\
\text { peaks above threshold (1 March-31 August) }\end{array}$ \\
\hline & $\begin{array}{c}\text { Autumn-winter } \\
\text { peak-over-threshold frequency }\end{array}$ & AWPOT3XF & $\begin{array}{c}\text { Annual number of autumn and winter discharge } \\
\text { peaks above threshold (1 September-28 (29) } \\
\text { February) }\end{array}$ \\
\hline
\end{tabular}

Remarkably, in this paper, the indicators of seasonal time series were distinguishing into spring-summer (March-August) and autumn-winter (September-February), which adapt to the seasonal characteristics of the Han River. For example, the annual springsummer maximum streamflow time series (ASSMDXS) consists of the largest daily mean discharge of the spring and summer periods of each year.

Additionally, the series with on average three independent flood events (POT3) per year before the reservoir started operation were selected. For the period of 10 years (1957-1966), the POT3 samples include the largest 30 independent discharge peaks. Differ- 
ent time intervals can well ensure the independence of different floods. In this paper, 7-, 15-, and 30-day intervals were attempted, and finally, 15 days was chosen as the suitable intervals. POT3 as the threshold values was used to select the magnitude of the flood events (POT3M) and the frequency per year (POT3F). Seasonal POT3 was distinguished into two seasons. For example, the frequency of the spring-summer peak-over-threshold (SSPOT3F) was counted from the independent flood events above the threshold in every spring and summer.

\subsection{Histogram Matching Approach (HMA)}

The most popular evaluation method of hydrological variation called Range of Variability Approach (RVA) [31] is usually used in water resources and ecosystem management by employing the preimpact (or unregulated) streamflow series to establish the indicators target ranges. Apart from the differences of indicators, the statistical evaluation method can be used both in ecohydrological regime variations and flood characteristic alterations. However, this paper used the Histogram Matching Approach (HMA) [32] instead of RVA, because it considered the difference of frequency distribution between the pre- and postimpact indicators series, which can better account for the sensitivity of the flood characteristic series in the part of frequency variation.

The principle of this method is based on the quadratic form distance between the frequency vectors of the pre- and postimpact histograms weighted by a specified similarity matrix. The specific procedural steps of HMA as follows:

a. For one hydrological indicator, before the histogram constructed, the number of classes $n c_{m}$ must be determined according to the whole data of the pre- and postimpact periods. The classification number of the histogram should not be too large or too small to express the frequency characteristics of data distribution effectively. The following formula is used in this study:

$$
n c_{m}=\operatorname{ceil}\left(r_{m} n_{m}^{1 / 3} / 2 r_{q, m}\right)
$$

where $\operatorname{ceil}(x)$ is the function for the smallest integer greater than or equal to $x, r_{m}$ is the difference between the largest and smallest data values, $n_{m}$ is total number of data, and $r_{q, m}$ is inter-quartile range, the difference between the $1 / 4$ and $3 / 4$ values.

b. After the histograms statistics of $H_{m}$ (preimpact) and $K_{m}$ (postimpact), the dissimilarity is measured by using a quadratic-form distance.

$$
d_{m}\left(H_{m}, K_{m}\right)=\sqrt{\left(\left|h_{m}-k_{m}\right|\right)^{T} A_{m}\left(\left|h_{m}-k_{m}\right|\right)}
$$

where $h_{m}=\left(h_{1, m}, h_{2, m}, \ldots, h_{n c_{m}, m}\right)^{T}$ and $k_{m}=\left(k_{1, m}, k_{2, m}, \ldots, h_{n c_{m}, m}\right)^{T}$ are frequency vectors of $H_{m}$ and $K_{m},\left|h_{m}-k_{m}\right|$ is statistical distance vector, and $A_{m}=\left[a_{i j, m}\right]$ is similarity matrix, where $a_{i j, m}$ is the similarity between classes $i$ and $j$. The formula of $a_{i j, m}$ as follows:

$$
a_{i j, m}=1-\frac{d_{i j, m}}{\max \left(d_{i j, m}\right)}
$$

where $d_{i j, m}=\left|V_{i, m}-V_{j, m}\right|$ is distance between classes $i$ and $j$, and $V_{i, m}$ and $V_{j, m}$ are the mean values of classes $i$ and $j$.

After calculating the dissimilarity $\left(d_{m}\right)$ between $H_{m}$ and $K_{m}$, the deviation evaluation of a postimpact flood indicator from the preimpact is defined as $D_{m}$, which is the normalized matrix of $d_{m}$. Thus, the $D_{m}$ can be employed to quantitatively analyze the variations of the flood characteristics selected.

\subsection{Multiple Trend Analysis}

The tendency of flood regime is important for flood evolution research. Generally, trends in a time series are sensitive to the selection of the investigation period and start 
and end years [33]. Therefore, the analysis of trends in flood characteristics is done for multiple periods with different start and end years, extending the previous trend analyses studies, which can avoid the trend presented only in a specific period, which may cover up other more trends characteristics of smaller investigation periods. Trend significance was tested with the nonparametric Mann-Kendall test [34], with significance levels of 0.05 and 0.01 . Multiple trends of the indicators for upstream inflow and downstream outflow were selected for analysis by the investigating time series of at least 20 years, and the lengths and variations are presented in $\mathrm{m}^{3} \cdot \mathrm{s} /$ decade. For the accuracy of the significance test, the indicators time series were pretreated to remove the lag1 correlation.

\section{Results}

\subsection{Flood Indicators Comparison between Pre-and Post-Operation Time Periods}

The calculation of the average, maximum, minimum, and coefficient of variation $(\mathrm{CV})$ were used to estimate the dispersion for these indicators in each data series for the preand post-operation periods, and the magnitude of the difference and deviation percentage were used to express the differences between the pre- and post-operation periods of the average and $C V$. The results showed that all the average values for the indicators of the post-operation period were smaller than the preoperation, but the $C V$ values became larger. The quantitative comparison results are provided in Table 2 . The specific analysis is as follows:

Table 2. The results of flood characteristics comparison quantified by the series of the indicators for Huangiagang hydrological station downstream of the Danjiangkou Reservoir between pre- and post-dam.

\begin{tabular}{|c|c|c|c|c|c|c|c|c|c|c|}
\hline \multirow{2}{*}{ Flood Indicators } & \multicolumn{4}{|c|}{ Preoperation } & \multicolumn{4}{|c|}{ Post-Operation } & \multirow{2}{*}{ DMA/\% ${ }^{b}$} & \multirow{2}{*}{$\mathrm{DMC} / \%^{\mathrm{c}}$} \\
\hline & ave & $\max$ & $\min$ & $C V^{\mathrm{a}}$ & ave & $\max$ & $\min$ & $C V$ & & \\
\hline \multicolumn{11}{|c|}{$\begin{array}{l}\text { magnitude of annual } \\
\text { and seasonal flood } \\
\left(\mathrm{m}^{3} / \mathrm{s}\right)\end{array}$} \\
\hline AMDXS & 14,997 & 27,400 & 3130 & 0.58 & 5068 & 20,057 & 829 & 0.89 & $-9929 / 0.66$ & $0.31 / 0.53$ \\
\hline ASSMDXS & 10,646 & 27,400 & 3130 & 0.77 & 3573 & 11,062 & 829 & 0.80 & $-7073 / 0.66$ & $0.03 / 0.04$ \\
\hline AAWMDXS & 9245 & 25,600 & 591 & 0.95 & 4850 & 20,057 & 637 & 1.06 & $-4395 /-0.48$ & $0.11 / 0.12$ \\
\hline \multicolumn{11}{|c|}{$\begin{array}{c}\text { magnitude-duration } \\
\text { of annual extreme } \\
\text { flood conditions }\left(\mathrm{m}^{3} / \mathrm{s}\right)\end{array}$} \\
\hline AM3DXS & 12,651 & 23,867 & 2460 & 0.60 & 5292 & 18,582 & 828 & 0.88 & $-7359 /-0.58$ & $0.28 / 0.47$ \\
\hline AM7DXS & 8886 & 16,174 & 2027 & 0.59 & 4507 & 13,748 & 740 & 0.81 & $-4379 /-0.49$ & $0.22 / 0.37$ \\
\hline AM15DXS & 6094 & 10,245 & 1333 & 0.55 & 3500 & 9818 & 687 & 0.71 & $-2594 /-0.43$ & $0.16 / 0.29$ \\
\hline AM30DXS & 4332 & 8609 & 1159 & 0.57 & 2693 & 7706 & 631 & 0.64 & $-1639 /-0.38$ & $0.07 / 0.12$ \\
\hline AM90DXS & 2607 & 5105 & 907 & 0.50 & 1861 & 5586 & 509 & 0.52 & $-746 /-0.29$ & $0.02 / 0.04$ \\
\hline \multicolumn{11}{|l|}{$\begin{array}{l}\text { peak-over-threshold } \\
\text { series }\end{array}$} \\
\hline РОT3M $\left(\mathrm{m}^{3} / \mathrm{s}\right)$ & 8077 & 16,352 & 2217 & 0.57 & 3779 & 12,693 & 812 & 0.75 & $-4298 /-0.53$ & $0.18 / 0.32$ \\
\hline РОТ3F & 1.2 & 3 & 0 & 0.95 & 0.29 & 3 & 0 & 2.23 & $-0.91 /-0.76$ & $1.28 / 1.35$ \\
\hline SSPOT3XF & 0.6 & 3 & 0 & 1.61 & 0.06 & 1 & 0 & 3.91 & $-0.54 /-0.9$ & $2.30 / 1.43$ \\
\hline AWPOT3XF & 0.6 & 3 & 0 & 1.61 & 0.23 & 2 & 0 & 2.25 & $-0.37 /-0.62$ & $0.64 / 0.40$ \\
\hline
\end{tabular}

${ }^{a} \mathrm{CV}$ (coefficient of variation) describes the average inter-annual variation for the pre- and post-operation time periods. ${ }^{\mathrm{b}}$ DMA/\% represents the difference between the pre- and post-operation time periods for the average and expresses as both a magnitude of difference and a deviation percentage. ${ }^{c}$ DMC \% represents the difference between the pre- and post-operation time periods in the coefficient of variation and expresses as both a magnitude of difference and a deviation percentage.

The deviation percentage of the averages for the individual attributes almost all decreased (Figure 3); in contrast, the deviation percentage of the $C V$ s increased with a range from 4\% (AM90DXF) to 143\% (POT3F). Such as the comparison of AMDXS and the hydrograph (Figure $3 \mathrm{a}$ ) showed that the relative differences of average decreased by $66 \%$ and $C V$ increased by $53 \%$, which means the operation of the reservoir reduced the magnitude of annual maximum flood flow and increased the inhomogeneous distribution 
of flood extreme events in the interannual period. Both in the spring-summer and autumnwinter periods, the annual seasonal maximum daily mean flow averages significantly decreased over $48 \%$, and the CVs were increased slightly below $12 \%$; the main reason probably was for guaranteeing the safety of flood control. The reservoir regulated the storage uniformly between seasons, and weakened the magnitude differences between seasonal floods.

For the statistics groups of the magnitude-duration of the annual extreme flood conditions, the DMAs and their percentages were significantly decreased, which means an obvious effect of the Danjiangkou Reservoir operation is the virtual elimination of the flood peak and volume in various duration scales from the upper basin. Besides, the DMCs of AM3DXS, AM7DXS, AM15DXS, AM30DXS, and AM90DXS were all increased, the maximum was $47 \%$ (AM3DXS); thus, the flood regulation of the reservoir not only makes the decrease on average but, also, an increasing trend in the deviation of flood magnitude at the interannual period. For the statistics group of the peak-over-threshold series, the DMA of POT3M decreased by 53\%, which compared to the preoperation period and the POT3F, reduced from 1.2 to 0.29 , which means the flood occurrence frequency magnitude over $8000 \mathrm{~m}^{3} / \mathrm{s}$ that happened every year in the pre-operation period was reduced to almost once in four years in the post-operation period. For SSPOT3XF and AWPOT3XF, we found that both of the average values were the same before the reservoir operated, which in SSPOT3XF and AWPOT3XF were 0.6, but in the post-operation period, the AWPOT3XF (0.23) was larger than SSPOT3F (0.06); this may be related to the law, which is that the reservoir mainly reduces the flood peak and impounds floodwater resources in the summer and keeps a relatively high water stage in the autumn. Due to the short data series in the pre-dam period, we need to further explore the corresponding relationship between the reservoir's inflow and outflow discharges by a long data series.
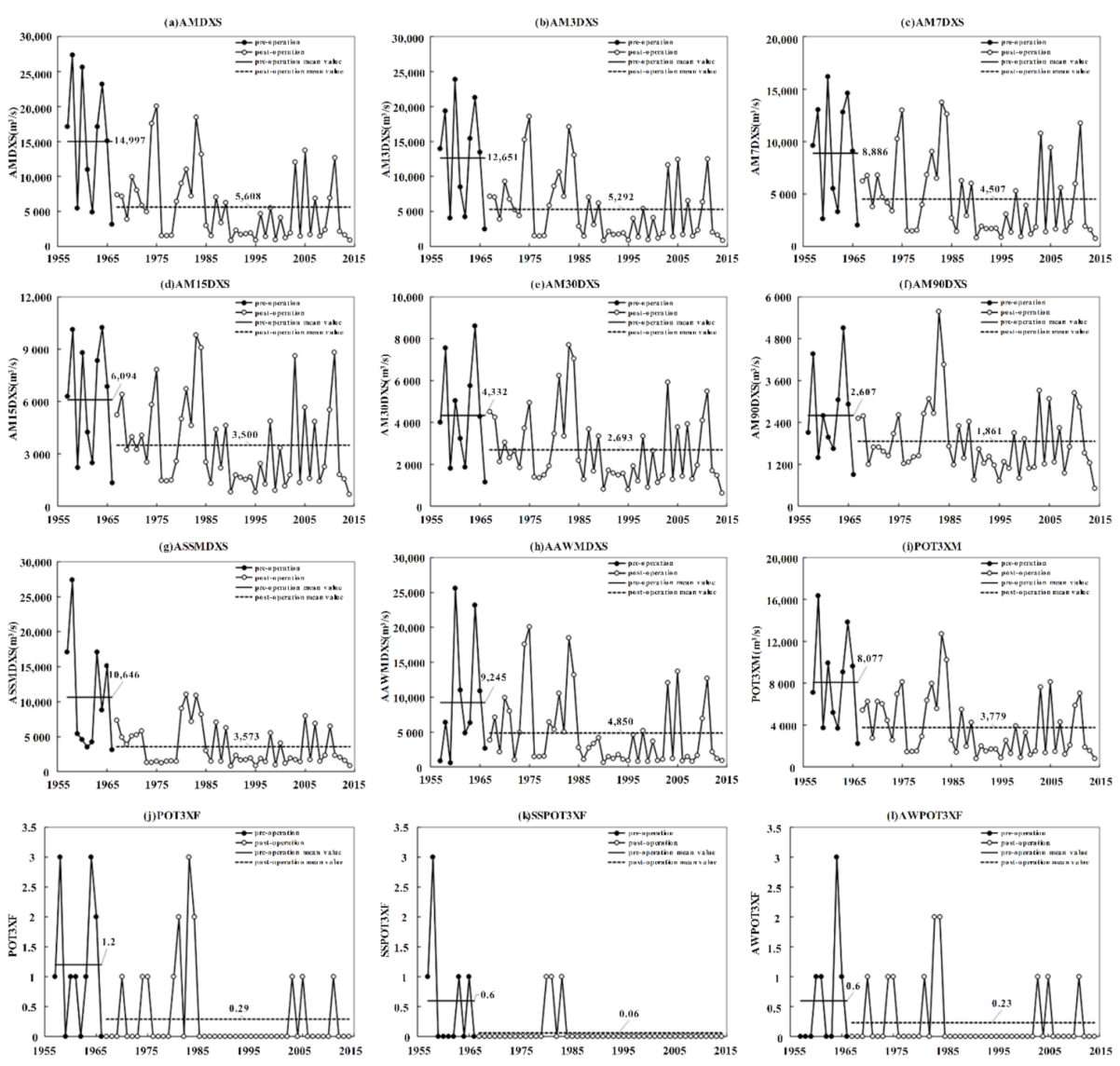

Figure 3. The flood characteristic indicators time series comparison between pre- and postoperation periods. 


\subsection{The Alteration Evaluation of Inflow and Outflow in Same Time Period}

For further study on the flood regulation of the Danjiangkou Reservoir and its effects on flood characteristics, we selected downstream outflow and upstream inflow processes of the reservoir in the same period (1969-2015) for comparative analysis. In this section, we used the HMA to evaluate the deviation of flood characteristics indicators. The flood indicators for outflow and inflow were compared in the histograms in Figure 4, and the evaluation of the flood alteration is provided in Table 3. The variation pattern of the indicators is similar to the previous Section 3.1. results; the indicators for average and maximum values of the downstream inflow are larger than upstream. For example, the DMA of AMDXS between the upstream inflow and downstream inflow is $-6070 \mathrm{~m}^{3} / \mathrm{s}$, and the deviation percentage is $52 \%$. Additionally, for the magnitude-duration of the annual extreme flood conditions, both the DMA and DMC for flood indicators showed a trend of decreasing with the increasing time scale. Among AM3DXS, AM7DXS, AM15DXS, AM30DXS, and AM90DXS, the maximum absolute deviation percentage of DMA and DMC were $46 \%$ and $52 \%$ which was for AM3DXS, and the minimum was $23 \%$ and $6 \%$, which is for AM90DXS. In terms of $C V$ values, the most significant alteration of indicators was SSPOT3XF, which belongs to the peak-over-threshold series. The average $C V$ value of the upstream inflow was 1.2, and the downstream outflow was 2.76 , which the latter was larger than the former by 1.56 , and the deviation percentage was $130 \%$.
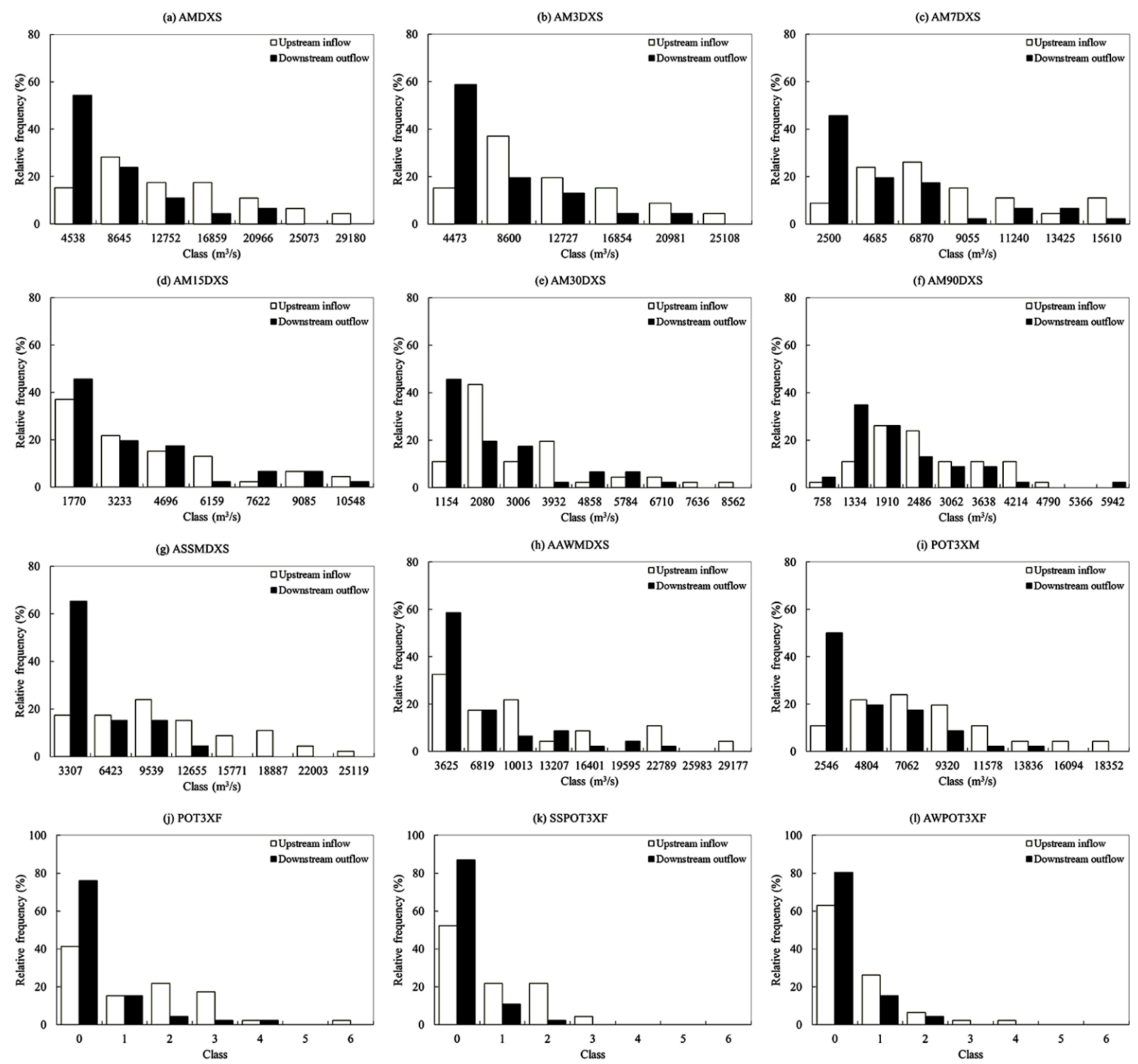

Figure 4. The flood characteristic indicators time series comparison between upstream inflow and downstream outflow. 
Table 3. The evaluation of flood indicators alteration between upstream inflow and downstream outflow.

\begin{tabular}{|c|c|c|c|c|c|c|c|c|c|c|c|}
\hline \multirow{2}{*}{ Flood Indicators } & \multicolumn{4}{|c|}{ Upstream Inflow } & \multicolumn{4}{|c|}{ Downstream Outflow } & \multirow{2}{*}{ DMA/\% ${ }^{b}$} & \multirow{2}{*}{$\mathrm{DMC} / \%^{\mathrm{c}}$} & \multirow{2}{*}{$\begin{array}{c}\mathrm{D} \\
\text { Value/\% }\end{array}$} \\
\hline & ave & $\max$ & $\min$ & $C V^{\mathrm{a}}$ & ave & $\max$ & $\min$ & $C V$ & & & \\
\hline \multicolumn{12}{|l|}{$\begin{array}{l}\text { magnitude of annual } \\
\text { and seasonal flood } \\
\left(\mathrm{m}^{3} / \mathrm{s}\right)\end{array}$} \\
\hline AMDXS & 11,606 & 29,174 & 431 & 0.59 & 5536 & 20,057 & 829 & 0.92 & $-6070 /-0.52$ & $0.33 / 0.56$ & 0.21 \\
\hline ASSMDXS & 9243 & 25113 & 191 & 0.62 & 3461 & 11,062 & 829 & 0.83 & $-5782 /-0.63$ & $0.21 / 0.34$ & 0.32 \\
\hline \multicolumn{12}{|l|}{$\begin{array}{c}\text { magnitude-duration } \\
\text { of annual extreme } \\
\text { flood conditions } \\
\left(\mathrm{m}^{3} / \mathrm{s}\right)\end{array}$} \\
\hline AM3DXS & 9634 & 25107 & 346 & 0.60 & 5214 & 18,582 & 828 & 0.91 & $-4420 /-0.46$ & $0.31 / 0.52$ & 0.28 \\
\hline AM7DXS & 6916 & 15,610 & 315 & 0.58 & 4421 & 13,748 & 740 & 0.84 & $-2495 /-0.36$ & $0.26 / 0.45$ & 0.20 \\
\hline AM15DXS & 4938 & 10,548 & 307 & 0.54 & 3399 & 9818 & 687 & 0.73 & $-1539 /-0.31$ & $0.19 / 0.35$ & 0.10 \\
\hline AM30DXS & 3663 & 8560 & 228 & 0.53 & 2619 & 7706 & 631 & 0.66 & $-1044 /-0.29$ & $0.13 / 0.25$ & 0.24 \\
\hline \multicolumn{12}{|l|}{$\begin{array}{c}\text { peak-over-threshold } \\
\text { series }\end{array}$} \\
\hline POT3M $\left(\mathrm{m}^{3} / \mathrm{s}\right)$ & 8077 & 16352 & 2217 & 0.57 & 3779 & 12,693 & 812 & 0.75 & $-4298 /-0.53$ & $0.18 / 0.32$ & 0.21 \\
\hline РОT3F & 1.32 & 6 & 0 & 1.06 & 0.93 & 4 & 0 & 2.19 & $-0.39 /-0.30$ & $1.13 / 1.07$ & 0.19 \\
\hline SSPOT3XF & 0.78 & 3 & 0 & 1.20 & 0.15 & 2 & 0 & 2.76 & $-0.63 /-0.81$ & $1.56 / 1.30$ & 0.21 \\
\hline AWPOT3XF & 0.54 & 4 & 0 & 1.63 & 0.24 & 2 & 0 & 2.19 & $-0.30 /-0.56$ & $0.56 / 0.34$ & 0.05 \\
\hline Mean value & & & & & & & & & & & 0.19 \\
\hline
\end{tabular}

${ }^{\mathrm{a}} \mathrm{CV}$ (coefficient of variation) describes the average interannual variation for the upstream inflow and downstream outflow. ${ }^{\mathrm{b}} \mathrm{DMA} / \%$ represents the difference between the inflow and outflow process for the average and is expressed as both a magnitude of difference and a deviation percentage. ${ }^{c}$ DMC\% represents the difference between the inflow and outflow process in the coefficient of variation and is expressed as both a magnitude of difference and a deviation percentage. ${ }^{\mathrm{d}} \mathrm{D}$ value/\% represents the dissimilarity degree between inflow and outflow process, which is calculated by the histogram matching approach (HMA).

Meanwhile, for $\mathrm{D}$ values that represent the dissimilarity degree between inflow and outflow process calculated by HMA, the mean degree of flood alteration was $19 \%$, and the dissimilarity degrees of almost all the indicators except AWPOT3XF were over $10 \%$, especially the AMDXS, AM3DXS, AM7DXS AM30DXS, POT3M, and SSPOT3XF were over $20 \%$, and the largest of ASSMDXS was 32\%. Figure 4 shows the change characteristics of the upstream inflow and downstream outflow of the reservoir. The histograms of all the indicators seem to present a similar change pattern. The downstream outflow histograms moved to the left of the upstream inflow histograms, indicating a decreasing trend in frequency at high magnitude intervals and an increasing trend at low magnitude intervals. Take ASSMDXS as an example; through HMA, we decided the class number was 8 and the interval step was $3116 \mathrm{~m}^{3} / \mathrm{s}$; at the class range of $3307 \mathrm{~m}^{3} / \mathrm{s}$, the relative frequency of inflow and outflow characteristics were increased from $17.39 \%$ to $65.22 \%$, and at the class range of $12655 \mathrm{~m}^{3} / \mathrm{s}$, the relative frequency decreased from $15.22 \%$ to $4.35 \%$. Thus, it can be seen that the reservoir played an important role in the flood characteristics alteration by regulated the storage, which weakened from the aspects of magnitude, duration, and frequency.

\subsection{Trend Changes of Flood Characteristics at Upstream and Downstream Reservoir}

From the results of the multiple-trend analysis (Figure 5), it can be seen that there is a common feature in all indicators. The increasing trend of upstream indicators from the 1970 s to 2010 s or 1980 s to 2010 s passing through the significant level of 0.05 was generally a single period, while the downstream indicators from the 1970s to 2000s or 1970s to 2010s showed two independent periods with increasing trends, which divided by the year around 1975. Among them, the upstream indicators' increasing trend was wider on the time scale. The specific analysis is shown below: 

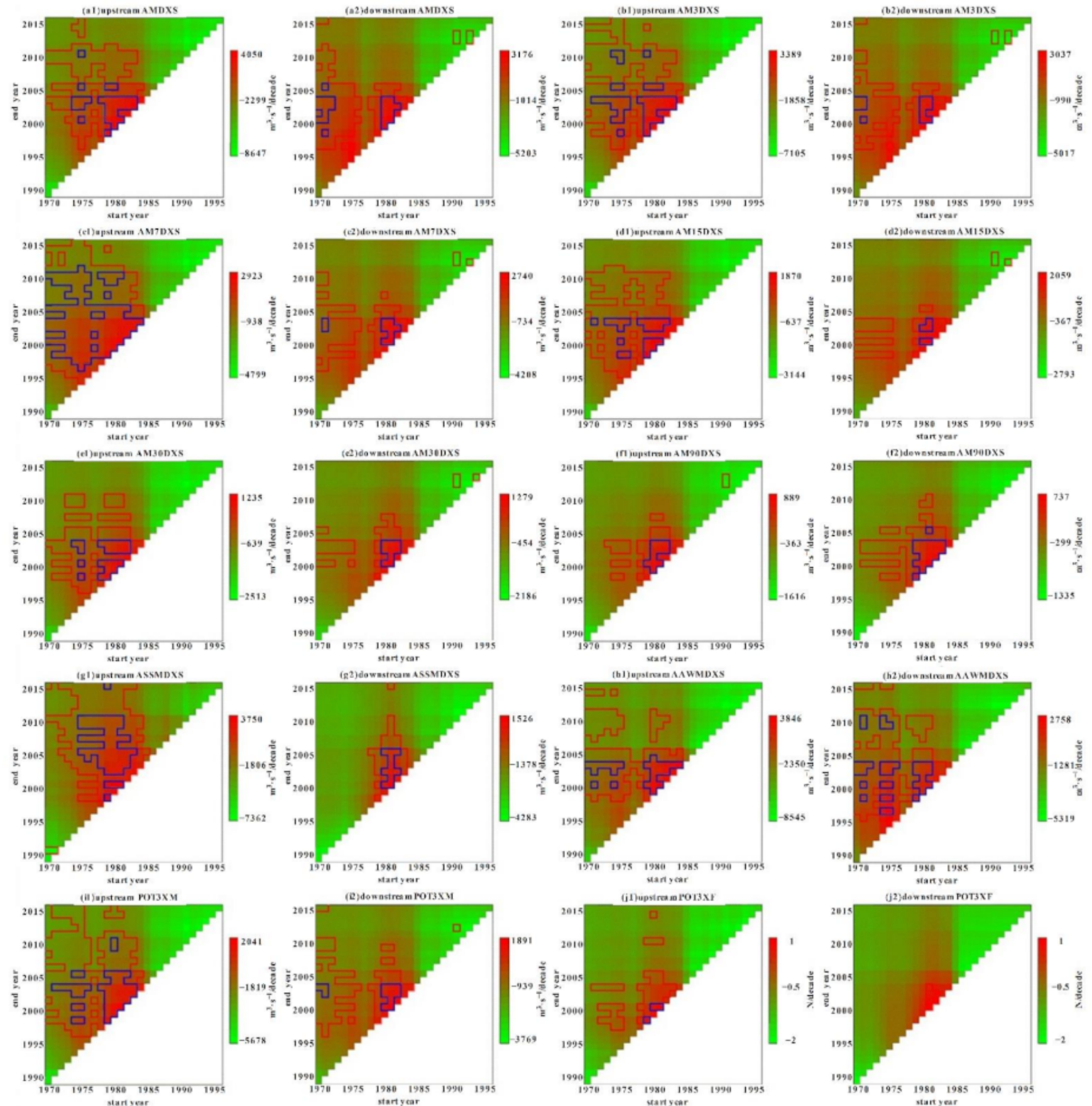

(k1) apstram SxPOT3Xr
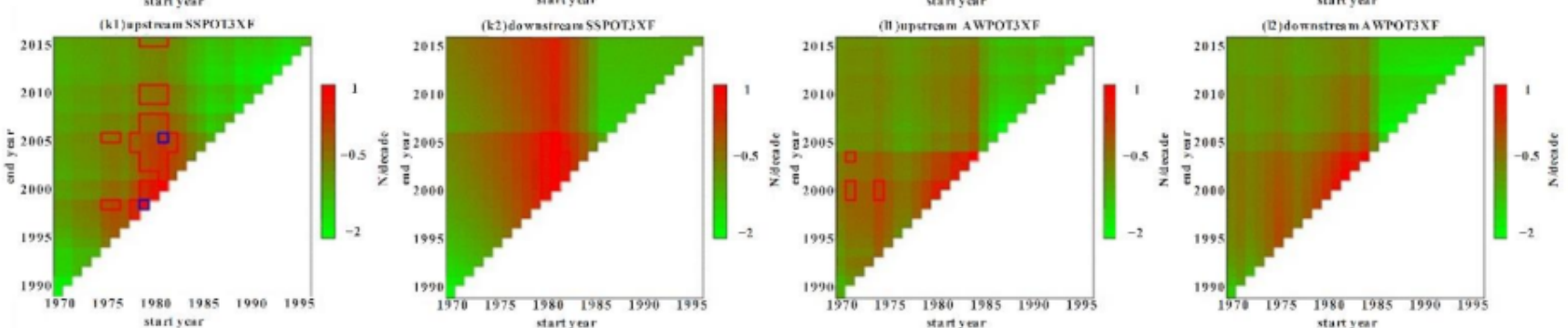

Figure 5. The flood characteristic indicators time series multiple Mann-Kendall trend analysis comparison between the upstream inflow and downstream outflow.

For the indicators of magnitude-duration of the annual extreme flood conditions, which are AMDXS, AM3DXS, AM7DXS, AM15DXS, AM30DXS, and AM90DXS, the up- 
stream of each indicator in the red line (passed the multiple Mann-Kendall trend test with the significance levels of 0.05 ) in the figure can form a whole region. The left border for the red line can be regarded as the starting point of the period, and the upper border can be regarded as the ending point. So that we can find such a law, the increasing trend of upstream indicators for AMDXS, AM3DXS, AM7DXS, AM15DXS, and AMD30DXS are basically from the 1970s to 2010s. However, for downstream indicators, the indicators mentioned above basically form two separate regions surrounded by the red line in the figure. From the time scale, one period is from the 1970s to 2010s, and the other is from 1975 to 2005 . For this phenomenon, we can understand that these two periods are in an inclusion relationship; in long periods of significantly increasing trends, there is a small period when the trend is not significant due to the time window set. Additionally, the area surround by red lines has become smaller for downstream indicators; this indicates that the impact of the reservoir plays a considerable role in the trend change of natural flow in the same section. It is worth mentioning that the area surrounded by red lines for AM90DXS of downstream is larger than upstream, which phenomenon is the opposite of the previous indicators. This may be exactly related to the homogenizing effect, because AM90DXS is calculated from the maximum mean discharge of 90 days each hydrological year.

For the indicators of the magnitude of the seasonal flood, the area surrounded by red lines for upstream ASSMDXS is much larger than downstream, and the increasing trend period passed the multiple Mann-Kendall trend test from 1970 to 2015 with the significance level of 0.05 and 1972 to 2010 with the significance level of 0.01 , while the downstream ASSMDXS showed an increasing trend from 1997 to 2010s, which passed the multiple Mann-Kendall trend test with the significance level of 0.05, and 2000 to 2005 with the significance level of 0.01 . In this same section of the reservoir, there is an obvious interannual scale between the periods of significant changes in the trends for upstream inflow and downstream outflow. For AAWMDXS, the patterns of change are generally similar between upstream and downstream, with the increasing trend period basically from the 1970 s to 2010 s.

For the indicators of the peak-over-threshold series, almost all the indicators of downstream outflow showed a shorter period than upstream inflow. For example, the increasing trend of upstream POT3XF passed the multiple Mann-Kendall trend test from 1973 to 2000 and 1976 to 2006 with the significance level of 0.05, while the downstream POT3XF passed the multiple Mann-Kendall trend test from 1978 to 2004 with the significance level of 0.05 . It can be seen that the reservoir with a large regulation capacity can significantly change the trend variation characteristics for the frequency of floods.

Overall, the Danjiangkou Reservoir began to store water for the first time in 1968, and the phase of the project was completed in 1974, and it was raised again in 2005 and completed in 2013. It can be seen that the characteristic of the obvious division of the trend of the upstream and downstream indicators was related to the change of runoff, also closely related to the construction and operation period of the project.

\section{Discussion}

This study analyzed the flood characteristics alteration induced by the Danjiangkou Reservoir; it can be summarized that the average value of each flood characteristics indicator of the post-dam period is larger than the pre-dam period, and the periods of inflow and outflow from the reservoir are asynchronous on a certain scale. Specifically, it can be divided into the following points for discussion:

\subsection{The Applicability of the Indicator System}

In this study, we constructed a flood characteristic indicator system covering magnitude, duration and frequency for the Danjiangkou Reservoir in the Han River Basin, and this provides a reference for flood impact evaluation for large reservoirs. All these indicators can be classified on different time scales according to the regulation capacity of the reservoir. For small reservoirs, we focus on a monthly/daily/sub-daily scale [35,36], and 
for large reservoirs, we focus on a seasonal/annual scale [37]. In addition to the characteristics of a flood generalized through the hydrological process, it is also related to the spatial patterns [38], geomorphology [39,40], rainfall, and climate [41,42]. Whether the indicators need to be considered more comprehensive or cover more content depends on the object for analysis. For the regional scale, we need to consider more factors including rainfall, spatial patterns, geomorphology, and other characteristics, but for a single water conservancy project, its attention should be focused on the flooding process, and the indicators can be customized components according to the actual situation in the framework of the system proposed in this study. Additionally, it should be noted that to avoid redundancy during the construction of indicators, the correlation of indicators needs to be analyzed and the types of indicators need to be screened.

\subsection{The Reservoir Has Changed the Magnitude of Flood Significantly}

From the results of this study, we can see that, under the impact of the Danjiangkou Reservoir, the magnitude indicators of the annual and seasonal flood have changed significantly. The function of the reservoir for the three indicators AMDXS, ASSMDXS, and AAWMDX are to reduce the mean and values whether it is from the same section of different period dimension or the same period with inflow and outflow space dimension. We interpreted these results as the reservoir with different regulation performances according to its design; in the state of stable inflow; and it usually plays the role for power generation, water supply, irrigation; and other beneficial purpose regulations. However, in case of floods, the reservoir will release the storage capacity in advance and store the flood later coming to ensure the flood control safety for itself and downstream. This can be clearly understood through the hydrograph of the reservoir's inflow and outflow (Figure 6). However, for flood control, reducing the flood peak downstream is beneficial for regional flood safety, but for the river ecosystem, it will reduce the exchange of energy, nutrients, and substances between the floodplain and the main river to a certain extent [43-45]; the reason is that, only when the flood magnitude reaches a certain level, the water stage rises to connected the main channel with floodplain and flows as a carrier to transport energy and materials in both directions. Therefore, it is of great significance to study the evaluation method of flood characteristics and enrich the connotation of indicators for evaluating the balance between flood prevention and ecological protection.

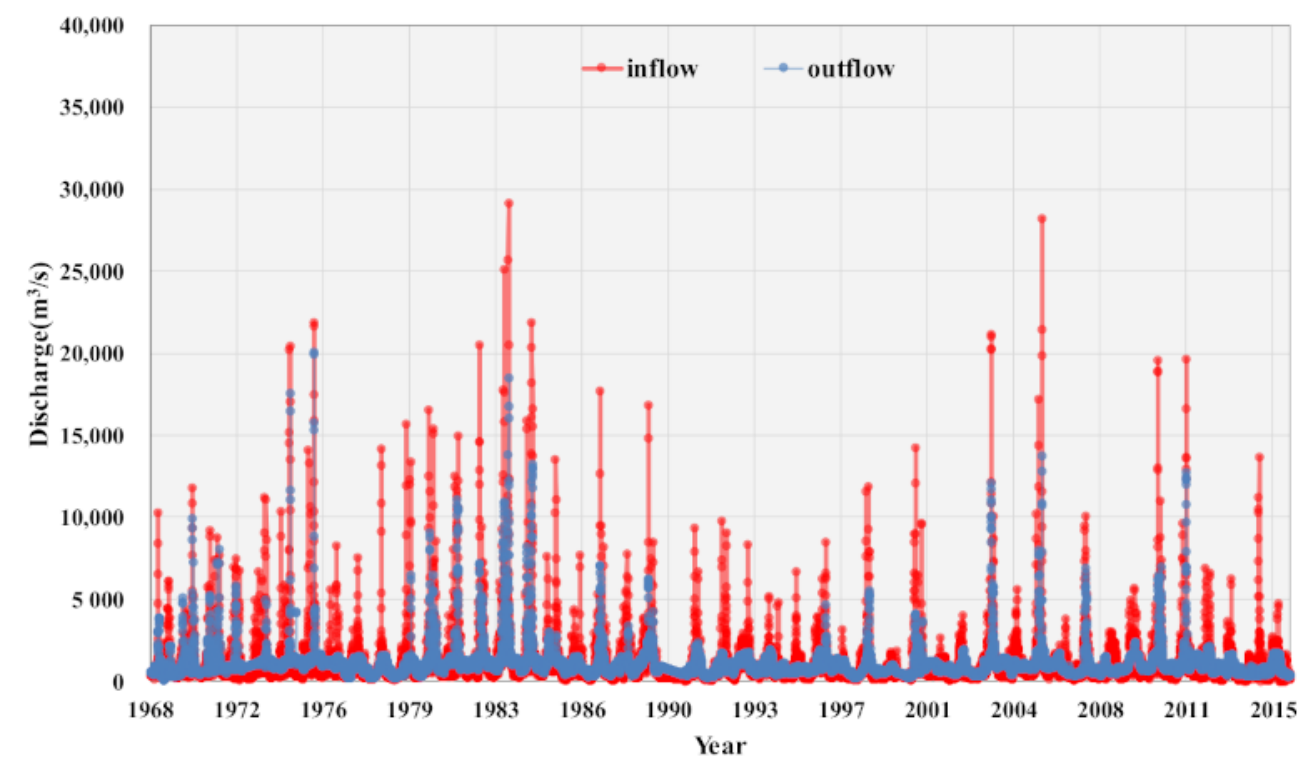

Figure 6. Hydrograph of inflow and outflow process of the Danjiangkou Reservoir. 


\subsection{The Reservoir Has Reduced the Flood Frequency of the Downstream Section Significantly}

This study established a set of indicators, which are POT3XM, POT3XF, SSPOT3XF, and AWPOT3XF, for statistical annual and seasonal flood frequency characteristics. It has shown that, whether the average value or the coefficient of variation for frequency indicator series, the statistical values of natural flood process is larger than the regulation; this can also be directly reflected by the correlation scatter plot of indicators for upstream and downstream in Figure 7. However, some previous studies have shown that the reservoir has two opposite patterns: homogenization and sharpening [46-48]. This phenomenon of reducing flood frequency by the reservoir is easy to explain; reservoirs are operated according to the scheduling regulations, and their sharpening effect on hydrological processes is often due to the hydropower generation when the inflow is stable. However, the rise and fall fluctuation of a river caused by hydropower generation is much lower than the threshold value of flood peaking judgment. During the reservoir impoundment for reasons such as flood control or rising water storage level, there is a flood peaking over the threshold value, and this homogenization effect comes out. Therefore, this shows that the reservoir can reduce the flood peaking frequency, which is over a certain threshold.

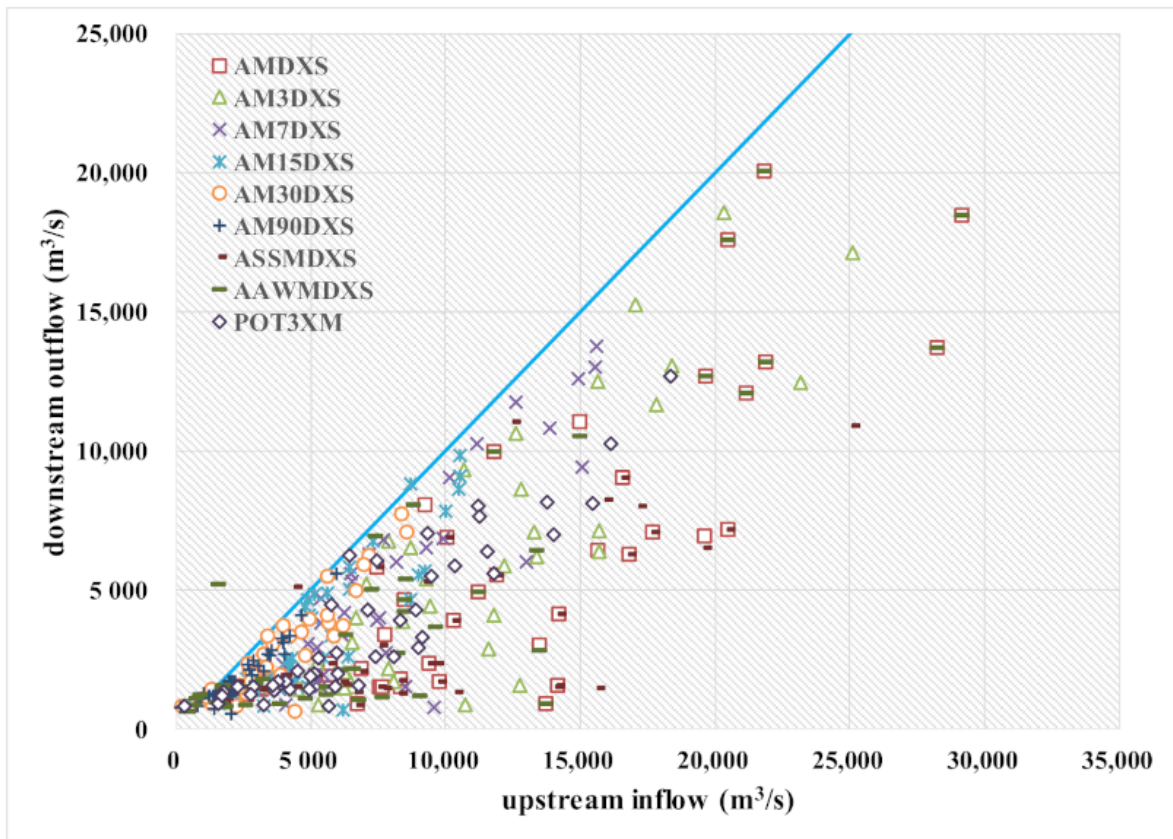

Figure 7. Correlation scatter plot of flood characteristics indicators for upstream and downstream.

\subsection{The Reservoir Has Changed the Trend and Periodicity of Flood Change in Adjacent River Sections}

In this study, the upstream inflow and downstream outflow flood characteristic indicator changing trends are analyzed by multiple Mann-Kendall tests. From the results, we can see that, under the impact of the reservoir, the changing trend of the flood characteristics of the same section presents an asynchronous state in which there is a significant difference between the upstream and downstream for indicators trend changing period. Previous studies [49-51] have shown that reservoirs profoundly impact the distribution of runoff at different time scales according to the regulation capacity, and this asynchronous phenomenon is closely related to the construction timing and operation period of reservoirs. The trend analysis in several dimensions such as flood magnitude, duration, and frequency shows that reservoirs have an all-around influence on flood processes and characteristics. A deep understanding of the changing regular on the trends of flood characteristics is important for flood control safety, but from the view of the ecosystem, this influence will also profoundly affect the evolution of the river and its surrounding systems. By reducing the frequency and shortening the duration of downstream floods, the energy and 
material exchange law between river and floodplain ecosystems has been changed [52-54]. Meanwhile, we need to be concerned about the potential effects of impoundments on the upstream reservoir, including the backwater zone. An increased water level and duration of high stages occurring may affect the surrounding habitats, especially the energy and material at the bank of the reservoir area, which may have a substantial implications for ecosystem functioning $[55,56]$.

\section{Conclusions}

Through the quantitative analysis method, it can be found that the Danjiangkou Reservoir has changed the flood characteristics to a great extent both of seasonal or annual floods, and the mean degree of the alteration is about $19 \%$. From the perspective of the changing trend, the flood indicators of upstream showed an increasing trend from the 1970s to 2010s, while downstream is divided into two periods by the year of about 1975 . This result is mainly due to the multiple trend analysis method adopted in this paper, thus avoiding the bias of trend analysis that may be caused by the time scale selection. It can be seen from the asynchronous trend of inflow and outflow flood indicators that reservoirs with large regulation capacities can change the original synchronous characteristics of floods in the same section of the river.

This paper systematically studied the flood alteration of Danjiangkou Reservoir by constructing quantitative indicators of flood characteristics using the HMA and multiple trend analysis methods, which can provide a reference for a deeper understanding of flood changes under the influence of hydraulic engineering.

Furthermore, the evaluation system for the quantitative analysis of flood characteristic alterations has proven to be effective in the Danjiangkou Reservoir. However, from the perspective of research, there are still some aspects worthy of our attention that need to be improved in the future. The first is the representativeness of the indicators. Although these indicators can preliminarily summarize the main characteristics of floods, the applicability and repeatability need to be further demonstrated for different rivers. The second is the evaluation method, in which we used the mean degree of the flood alteration calculated by the HMA to evaluate the overall alteration degree of the flood. However, the representation degree of each flood indicator is different, so the various indicators' weight for flood characteristic alterations deserve further study.

Finally, it is worth mentioning that the value of the flood characteristics indicators system is that it can quantify the characteristics of floods from multiple dimensions; its basic framework mainly includes elements such as magnitude, frequency, duration, etc. For specific objects, a specific indicators system needs to be constructed and iteratively improved on its basis through continuous analysis to meet the needs of evaluation.

Author Contributions: X.Z., B.F., and J.Z. worked together in forming the ideas of this paper; X.Z., B.F., Y.X., J.L., W.N., and Y.Y. worked together in the calculating and writing of this manuscript. X.Z. and J.Z. provided supervision during the whole process. All authors have read and agreed to the published version of the manuscript.

Funding: This research was funded by the National Key R\&D Program of China (no. 2018YFC1508002) and Hubei Provincial Natural Science Foundation of China (no. 2020CFB340).

Institutional Review Board Statement: Not applicable.

Informed Consent Statement: Not applicable.

Data Availability Statement: Restrictions apply to the availability of these data. Data was obtained from Bureau of Hydrology, Changjiang Water Resources Commission and are available from the authors with the permission of Bureau of Hydrology, Changjiang Water Resources Commission.

Conflicts of Interest: The authors declare no conflict of interest. The funding sponsors had no role in the design of the study; in the collection, analyses, or interpretation of data; in the writing of the manuscript; or in the decision to publish the results. 


\section{References}

1. Middelkoop, H.; Daamen, K.; Gellens, D.; Grabs, W.; Kwadijk, J.C.J.; Lang, H.; Parmet, B.W.A.H.; Schädler, B.; Schulla, J.; Wilke, K. Impact of Climate Change on Hydrological Regimes and Water Resources Management in the Rhine Basin. Clim. Chang. 2001, 49, 105-128. [CrossRef]

2. Kay, A.; Davies, H.N.; Bell, V.A.; Jones, R.G. Comparison of uncertainty sources for climate change impacts: Flood frequency in England. Clim. Chang. 2009, 92, 41-63. [CrossRef]

3. Criss, R.E.; Luo, M. Increasing risk and uncertainty of flooding in the Mississippi River basin. Hydrol. Process. 2017, 31, 1283-1292. [CrossRef]

4. Tang, Y.; Xi, S.; Chen, X.; Lian, Y. Quantification of Multiple Climate Change and Human Activity Impact Factors on Flood Regimes in the Pearl River Delta of China. Adv. Meteorol. 2015, 2016, 1-11. [CrossRef]

5. Linde, A.H.T.; Aerts, J.; Kwadijk, J.C.J. Effectiveness of flood management measures on peak discharges in the Rhine basin under climate change. J. Flood Risk Manag. 2010, 3, 248-269. [CrossRef]

6. Van Der Knijff, J.M.; Younis, J.; De Roo, A.P.J. LISFLOOD: A GIS-based distributed model for river basin scale water balance and flood simulation. Int. J. Geogr. Inf. Sci. 2010, 24, 189-212. [CrossRef]

7. Liang, Q. Flood Simulation Using a Well-Balanced Shallow Flow Model. J. Hydraul. Eng. 2010, 136, 669-675. [CrossRef]

8. Turcotte, R.; Rousseau, A.N.; Fortin, J.-P.; Villeneuve, J.-P. A process-oriented, multiple-objective calibration strategy accounting for model structure. Water Sci. Appl. 2003, 6, 153-163. [CrossRef]

9. Mediero, L.; Santillan, D.; Garrote, L.; Granados, A. Detection and attribution of trends in magnitude, frequency and timing of floods in Spain. J. Hydrol. 2014, 517, 1072-1088. [CrossRef]

10. Maurer, E.P.; Stewart, I.T.; Bonfils, C.; Duffy, P.B.; Cayan, D. Detection, attribution, and sensitivity of trends toward earlier streamflow in the Sierra Nevada. J. Geophys. Res. Space Phys. 2007, 112. [CrossRef]

11. Poff, N.L. Ecological response to and management of increased flooding caused by climate change. Philos. Trans. R. Soc. A Math. Phys. Eng. Sci. 2002, 360, 1497-1510. [CrossRef] [PubMed]

12. Rajib, A.; Liu, Z.; Merwade, V.; Tavakoly, A.A.; Follum, M.L. Towards a large-scale locally relevant flood inundation modeling framework using SWAT and LISFLOOD-FP. J. Hydrol. 2020, 581, 124406. [CrossRef]

13. Tian, J.; Yuan, Z.; Jia, B.; Li, M.; Jiang, G. The Stabilization Effect of the Density Dif-ference in the Modified Lattice Hydrodynamic Model of Traffic Flow. Phys. A Stat. Mech. Appl. 2012, 391, 19-4476. [CrossRef]

14. Liu, Z.; Venkatesh, M. Separation and Prioritization of Uncertainty Sources in a Raster Based Flood In-undation Model Using Hierarchical Bayesian Model Averaging. J. Hydrol. 2019, 578, 124100. [CrossRef]

15. Tabari, H. Extreme value analysis dilemma for climate change impact assessment on global flood and extreme precipitation. J. Hydrol. 2021, 593, 125932. [CrossRef]

16. Lima, C.H.R.; Lall, U. Hierarchical Bayesian modeling of multisite daily rainfall occurrence: Rainy season onset, peak, and end. Water Resour. Res. 2009, 45. [CrossRef]

17. Coscarelli, R.; Caloiero, T. Analysis of Daily and Monthly Rainfall Concentration in Southern Italy (Calabria Region). J. Hydrol. 2012, 416, 145-156. [CrossRef]

18. Szolgay, J.; Parajka, J.; Kohnová, S.; Hlavčová, K. Comparison of mapping approaches of design annual maximum daily precipitation. Atmos. Res. 2009, 92, 289-307. [CrossRef]

19. Villarini, G.; Smith, J.A.; Serinaldi, F.; Ntelekos, A.A. Analyses of seasonal and annual maximum daily discharge records for central Europe. J. Hydrol. 2011, 399, 299-312. [CrossRef]

20. Ward, P.; Van Pelt, S.; De Keizer, O.; Aerts, J.; Beersma, J.; Hurk, B.V.D.; Linde, A.T. Including climate change projections in probabilistic flood risk assessment. J. Flood Risk Manag. 2013, 7, 141-151. [CrossRef]

21. Parajka, J.; Kohnová, S.; Bálint, G.; Barbuc, M.; Borga, M.; Claps, P.; Cheval, S.; Dumitrescu, A.; Gaume, E.; Hlavčová, K.; et al. Seasonal characteristics of flood regimes across the Alpine-Carpathian range. J. Hydrol. 2010, 394, 78-89. [CrossRef] [PubMed]

22. Poff, N.; LeRoy, J.; Allan, D.; Bain, M.B.; Karr, J.R.; Prestegaard, K.L.; Richter, B.D.; Sparks, R.E.; Stromberg, J.C. The Natural Flow Regime. a Paradigm for River Conservation and Restoration. BioScience 1997, 47, 769-784. [CrossRef]

23. Richter, B.D.; Baumgartner, J.V.; Powell, J.; Braun, D.P. A Method for Assessing Hydrologic Alteration within Ecosystems. Conserv. Biol. 1996, 10, 1163-1174. [CrossRef]

24. Zhaohui, L.; Zhu, Y.; Lin, Z.; Wang, J.; He, G.; Li, H.; Li, L.; Wang, H.; Jiang, S.; He, F.; et al. Energy Reduction Effect of the South-to-North Water Diversion Project in China. Sci. Rep. 2017, 7, 1-9. [CrossRef]

25. Zhou, Y.; Guo, S.; Hong, X.; Chang, L.-C. Systematic impact assessment on inter-basin water transfer projects of the Hanjiang River Basin in China. J. Hydrol. 2017, 553, 584-595. [CrossRef]

26. Mallakpour, I.; Villarini, G. Investigating the relationship between the frequency of flooding over the central United States and large-scale climate. Adv. Water Resour. 2016, 92, 159-171. [CrossRef]

27. Razmi Ali, G.S.; Zahmatkesh, Z. Non-Stationary Frequency Analysis of Extreme Water Level: Ap-plication of Annual Maximum Series and Peak-over Threshold Approaches. Water Resour. Manag. 2017, 31, 2065-2083. [CrossRef]

28. Archfield, S.; Hirsch, R.; Viglione, A.; Blöschl, G. Using a Peaks-over-Threshold Approach to Assess Changes in Flood Magnitude, Volume, Duration, and Frequency across the United States; EGU: Munich, Germany, 2014; Volume 16.

29. Kusumastuti, D.I.; Struthers, I.; Sivapalan, M.; Reynolds, D.A. Threshold effects in catchment storm response and the occurrence and magnitude of flood events: Implications for flood frequency. Hydrol. Earth Syst. Sci. 2007, 11, 1515-1528. [CrossRef] 
30. Halgamuge, M.N.; Nirmalathas, A. Analysis of large flood events: Based on flood data during 1985-2016 in Australia and India. Int. J. Disaster Risk Reduct. 2017, 24, 1-11. [CrossRef]

31. Richter, B.; Baumgartner, J.V.; Wigington, R.; Braun, D.P. How much water does a river need? Freshw. Biol. 1997, 37, 231-249. [CrossRef]

32. Shiau, J.-T.; Wu, F.-C. A Histogram Matching Approach for assessment of flow regime alteration: Application to environmental flow optimization. River Res. Appl. 2008, 24, 914-928. [CrossRef]

33. Kundzewicz, Z.; Merz, B.; Vorogushyn, S.; Hartmann, H.; Duethmann, D.; Wortmann, M.; Huang, S.; Su, B.; Jiang, T.; Krysanova, V. Analysis of changes in climate and river discharge with focus on seasonal runoff predictability in the Aksu River Basin. Environ. Earth Sci. 2015, 73, 501-516. [CrossRef]

34. Yue, S.; Pilon, P.; Cavadias, G. Power of the Mann-Kendall and Spearman's rho tests for detecting monotonic trends in hydrological series. J. Hydrol. 2002, 259, 254-271. [CrossRef]

35. Bevelhimer, M.S.; A McManamay, R.; Oconnor, B.L. Characterizing Sub-Daily Flow Regimes: Implications of Hydrologic Resolution on Ecohydrology Studies. River Res. Appl. 2015, 31, 867-879. [CrossRef]

36. Sellami, H.; Benabdallah, S.; La Jeunesse, I.; Vanclooster, M. Climate models and hydrological parameter uncertainties in climate change impacts on monthly runoff and daily flow duration curve of a Mediterranean catchment. Hydrol. Sci. J. 2016, 61, 1415-1429. [CrossRef]

37. Frolov, A.V.; Georgievskii, V.Y. Changes in Water Resources under Conditions of Climate Warming and Their Impact on Water Inflow to Russian Large Reservoirs. Russ. Meteorol. Hydrol. 2018, 43, 390-396. [CrossRef]

38. Yang, T.; Xu, C.-Y.; Shao, Q.-X.; Chen, X. Regional flood frequency and spatial patterns analysis in the Pearl River Delta region using L-moments approach. Stoch. Environ. Res. Risk Assess. 2009, 24, 165-182. [CrossRef]

39. Woltemade, C.J. Form and Process: Fluvial Geomorphology and Flood-Flow Interaction, Grant River, Wis-consin. Ann. Assoc. Am. Geograph. 1994, 84, 462-479. [CrossRef]

40. Beven, K. Towards the use of catchment geomorphology in flood frequency predictions. Earth Surf. Process. Landforms 1987, 12, 69-82. [CrossRef]

41. Dankers, R.; Christensen, O.B.; Feyen, L.; Kalas, M.; De Roo, A. Evaluation of very high-resolution climate model data for simulating flood hazards in the Upper Danube Basin. J. Hydrol. 2007, 347, 319-331. [CrossRef]

42. Bouwer, L.M.; Bubeck, P.; Aerts, J.C.J.H. Changes in Future Flood Risk Due to Climate and De-velopment in a Dutch Polder Area. Global Environ. Change Hum. Policy Dimens. 2010, 20, 463-471. [CrossRef]

43. Poff, N.L.; Olden, J.D.; Merritt, D.M.; Pepin, D.M. Homogenization of regional river dynamics by dams and global biodiversity implications. Proc. Natl. Acad. Sci. 2007, 104, 5732-5737. [CrossRef]

44. Sparks, R.E. Need for Ecosystem Management of Large Rivers and Their Floodplains These Phenomenally Pro-ductive Ecosystems Produce Fish and Wildlife and Preserve Species. BioScience 1995, 45, 168-182. [CrossRef]

45. Thoms, M. Floodplain-river ecosystems: Lateral connections and the implications of human interference. Geomorphology 2003, 56, 335-349. [CrossRef]

46. Yan, B.; Zhang, X.; Chen, Y.B.; Yao, L.Q.; Huang, F.; Chen, Q.H.; Gao, Q.S.; Zhang, L.G.; Guo, L.D. Analysis of variation characteristics of runoff at multi-time scales under the influence of reservoir. IOP Conf. Series: Earth Environ. Sci. 2019, 344, 012165. [CrossRef]

47. Chen, Y.; Zhang, X.; Li, J.; Yan, B.; Chen, Q.; Xu, B.; Yao, L. Analysis of the Influence of Res-ervoir Regulation on the Multi-Scale Periodic Effect of Runoff Time Series. IOP Conf. Ser. Earth Environ. Sci. 2020, 560, 12042. [CrossRef]

48. Huang, F.; Chen, Q.; Li, F.; Zhang, X.; Chen, Y.; Xia, Z.; Qiu, L. Reservoir-Induced Changes in Flow Fluctuations at Monthly and Hourly Scales: Case Study of the Qingyi River, China. J. Hydrol. Eng. 2015, 20, 05015008. [CrossRef]

49. Zhang, Y.; Zheng, H.; Herron, N.; Liu, X.; Wang, Z.; Chiew, F.H.; Parajka, J. A framework estimating cumulative impact of damming on downstream water availability. J. Hydrol. 2019, 575, 612-627. [CrossRef]

50. Chen, Q.; Zhang, X.; Chen, Y.; Li, Q.; Qiu, L.; Liu, M. Downstream Effects of a Hydropeaking Dam on Ecohydrological Conditions at Subdaily to Monthly Time Scales. Ecol. Eng. 2015, 77, 40-50. [CrossRef]

51. Wang, H.; Sun, F.; Liu, W. Characteristics of streamflow in the main stream of Changjiang River and the impact of the Three Gorges Dam. Catena 2020, 189, 104498. [CrossRef]

52. Ribeiro, J.; Bentes, L.; Coelho, R.; Gonçalves, J.M.; Lino, P.G.; Monteiro, P.; Erzini, K. Seasonal, tidal and diurnal changes in fish assemblages in the Ria Formosa lagoon (Portugal). Estuar. Coast. Shelf Sci. 2006, 67, 461-474. [CrossRef]

53. Bouwman, A.F.; Bierkens, M.; Griffioen, J.; Hefting, M.M.; Middelburg, J.J.; Middelkoop, H.; Slomp, C.P. Nutrient dynamics, transfer and retention along the aquatic continuum from land to ocean: Towards integration of ecological and biogeochemical models. Biogeosciences 2013, 10, 1-22. [CrossRef]

54. Li, Y.; Acharya, K.; Yu, Z. Modeling impacts of Yangtze River water transfer on water ages in Lake Taihu, China. Ecol. Eng. 2011, 37, 325-334. [CrossRef]

55. Liro, M. Dam Reservoir Backwater as a Field-Scale Laboratory of Human-Induced Changes in River Biogeomor-phology: A Review Focused on Gravel-Bed Rivers. Sci. Total Environ. 2019, 651, 2899-2912. [CrossRef] [PubMed]

56. Wang, X.-R.; Cheng, R.; Feng, X.-H.; Guo, Q.-S.; Xiao, W.-F. Characteristics of soil seed banks in backwater area of Three Gorges Reservoir water-level-fluctuating zone at initial stage of river-flooding. J. Appl. Ecol. 2009, 20, 2891-2897. 